A N N A L E S

UNIVER S T ATIS M A R A E C URIE-SKŁODOW K A

LUBLIN - POLONIA

VOL. XXXIII, 1

SECTIO J

2020

Uniwersytet Łódzki. Wydział Nauk o Wychowaniu

\title{
ANNA JARKIEWICZ
}

ORCID: 0000-0002-9367-6258

anna.jarkiewicz@uni.lodz.pl

\section{Diagnoza interpretatywna jako „,nowy” sposób diagnozowania problemów w pracy socjalnej/społecznej}

Interpretative Assessment as a "New" Approach to Assessing the Problems in Social Work

PropozycJa CYtowania: Jarkiewicz, A. (2020). Diagnoza interpretatywna jako „nowy” sposób diagnozowania problemów w pracy socjalnej/społecznej. Annales Universitatis Mariae Curie-Skłodowska. Sectio J, Paedagogia-Psychologia, 33(1), 39-53. DOI: http://dx.doi.org/10.17951/j.2020.33.1.39-53.

\section{STRESZCZENIE}

W niniejszym artykule przybliżono założenia teoretyczno-metodologiczne diagnostyki interpretatywnej wraz z praktycznymi implikacjami jej zastosowania. Prezentacje ,,nowego” sposobu diagnozowania $\mathrm{w}$ pracy socjalnej przedstawiono $\mathrm{w}$ odniesieniu do powszechnie stosowanej $\mathrm{w}$ instytucjach związanych z pracą socjalną/społeczną diagnozy normatywnej. Analiza obu sposobów rozpoznawania problemów w pracy socjalnej została skierowana na ukazanie odmienności tych podejść w ich wymiarze teoretycznym, metodologicznym i praktycznym. W celu uzupełnienia wywodu wykorzystano przykład empiryczny - diagnozę jednego przypadku, ale dokonaną w dwóch ujęciach. Diagnozy normatywna i interpretatywna pochodzą z dwóch zajęć przeprowadzonych w ramach kształcenia dla studentów pedagogiki społecznej na poziomie licencjackim. W trakcie studiów studenci mają obowiązek przeprowadzić diagnozę przypadku w ujęciu normatywnym w ramach przedmiotu kształcenie umiejętności diagnostycznych, natomiast w ramach zajęć elementy diagnostyki interpreatywnej analizują ten sam przypadek, bazując na odmiennych od normatywnych założeniach teoretyczno-metodologicznych.

Słowa kluczowe: diagnoza interpretatywna; diagnoza normatywna; praca socjalna; praca społeczna

\section{WPROWADZENIE}

W Katedrze Pedagogiki Społecznej Uniwersytetu Łódzkiego od około 10 lat w ofercie przedmiotów dla studentów pedagogiki społecznej (III rok, I stopień) 
dostępne są zajęcia elementy diagnostyki interpretatywnej w pracy pedagoga społecznego. Celem tego przedmiotu jest zapoznanie studenta $\mathrm{z}$ interpretatywnymi koncepcjami umożliwiającymi inne spojrzenie na diagnozowany problem oraz zaprojektowanie określonych działań społeczno-pedagogicznych, które są wynikiem diagnozy przeprowadzonej w ujęciu interpretatywnym. „Inne spojrzenie” jest możliwe do uchwycenia poprzez porównanie wyników diagnozy interpretatywnej ze wcześniejszą diagnozą tego samego przypadku ${ }^{1}$, ale dokonaną w oparciu o tradycyjne metody rozpoznawania problemów społeczno-pedagogicznych (np. Ziemski, 1973; Lepalczyk, Badura, 1987; Marynowicz-Hetka, 1987; Mazurkiewicz, 1987; Jarosz, 2001; Jarosz, Wysocka, 2006). Ta „tradycyjna” diagnoza przeprowadzana jest przez studentów w roku poprzedzającym rozpoczęcie kursu z diagnostyki interpretatywnej w ramach przedmiotu kształcenie umiejętności diagnostycznych.

Dla osób prowadzących przedmiot zaskakujące jest to, jak zmiana optyki potrafi zmienić diagnozę problemu i tym samym przyszłą orientację działania. W niniejszym tekście została zaprezentowana idea diagnostyki interpretatywnej (założenia teoretyczne, implikacje praktyczne oraz wyzwania i trudności w jej stosowaniu), opisano także konkretny przypadek diagnozy normatywnej i interpretatywnej dokonanej przez studentkę, aby pokazać różnice w sposobie rozpoznawania i interpretowania problemów socjalnych/społecznych w tych dwu koncepcjach.

\section{DIAGNOSTYKA NORMATYWNA VS DIAGNOSTYKA INTERPRETATYWNA}

Jednym z ważniejszych elementów działania w pracy socjalnej/społecznej jest diagnoza. Co do tego stanowiska wśród badaczy społecznych, którzy na co dzień często reprezentują inne poglądy, panuje zgoda (np. Richmond, 1917; Marynowicz-Hetka, 1987; Joachimowska, 2012; Granosik, 2013b). Pisząc ,inne poglądy", mam na myśli odniesienia teoretyczne poszczególnych badaczy, których konsekwencją jest odmienna propozycja diagnozowania problemów społecznych. Dotychczasowe metody diagnozowania w polu pracy socjalnej/społecznej można podzielić analogicznie do propozycji Thomasa P. Wilsona (1973) na diagnozowanie typu normatywnego (diagnostyka normatywna) oraz diagnozowanie typu interpretatywnego (diagnostyka interpretatywna).

Diagnoza normatywna. Celem diagnozy normatywnej jest określenie, opisanie, wyjaśnienie (np. Soulet, 1996), dokonanie pomiaru (np. Kamiński, 1974; Wroczyński, 1974), a nawet przeprowadzenie oceny i ewaluacji (np. Joachimowska, 2012) zjawisk i problemów w ich wymiarze jednostkowym i/lub społecznym. Ten model uprawiania diagnozy inspirowany jest przede wszystkim podejściami teoretycznymi

1 Rodzinę bądź osobę, której problem (problemy) jest diagnozowany, student poznaje podczas praktyk śródrocznych. 
z obszaru nauk przyrodniczych, medycznych czy psychologicznych, które stanowiły i często nadal stanowią dominujący wzór odniesienia dla nauk pedagogicznych czy społecznych (Urbaniak-Zając, 2004, s. 104). W tej optyce podstawą do konstruowania narzędzi diagnostycznych jest odwołanie do pojęcia normy (np. zachowania czy działania), do określenia której: „(...) niezbędna jest znajomość wyników badań [zazwyczaj ilościowych - A.J.] nad interesującym problemem, danych statystycznych, demograficznych itp." (Marynowicz-Hetka, 2006, s. 123). Upraszczając, wynikiem takiej diagnozy jest określenie stopnia odstępstwa badanego przypadku od normy oraz zaplanowanie działań, które by go do tej normy zbliżyło.

Podstawowym zarzutem podkreślanym przez zwolenników podejść krytycznych (w tym podejścia interpretatywnego) wobec powyższego sposobu rozumowania jest istniejące $\mathrm{w}$ nim założenie, że analogiczne procesy zachodzą zarówno w świecie społecznym, jak i przyrodniczym (Weick, 1991). Konsekwencją tego toku myślenia jest przekonanie o uniwersalności i powszechności norm, co w kontekście diagnostyki sprzyja poglądowi, że czyjeś zachowania bądź „działania można mierzyć i kwalifikować niezależnie od innych zjawisk społecznych" (Blau, 2017, s. 80). Warto w tym miejscu podkreślić, że logika działania klientów pomocy społecznej jest często niezrozumiała, a niekiedy wręcz pozbawiona sensu dla reprezentantów profesji społecznych. Pomimo to praktycy zobowiązani są do wythumaczenia, zmierzenia i dokonania oceny stopnia zaburzenia diagnozowanych jednostek (często w odniesieniu do własnego systemu aksjonormatywnego), a następnie zaplanowania planu działania, którego celem jest eliminacja bądź redukcja odbiegających od normy zachowań czy też pomoc w adaptacji do środowiska. Zgodnie z wynikami wielu badań, w tym m.in. prowadzonych przez Williama P. Henry’ego i współpracowników (Henry, Strupp, Butler, Schacht, Binder, 1993), prezentowany powyżej porządek działania - od diagnozy (normatywnej), poprzez wdrażanie planu naprawczego, do ewaluacji - sprawia, że klienci czują, że są poddawani jakiejś interwencji, w którą w ogóle nie są zaangażowani. Jak piszą wspomniani autorzy, obecny w tym modelu specyficzny podział ról (specjalista, klient) nie sprzyja budowaniu relacji czy tworzeniu atmosfery zaufania, których istotność w pracy socjalnej tak często jest akcentowana przez wielu badaczy i praktyków społecznych; wręcz przeciwnie - prowadzi on do niespodziewanego pogorszenia się pewnych interpersonalnych i interakcyjnych aspektów pracy z przypadkiem. Według badań Henry'ego i współpracowników klienci pracę takiego pracownika często oceniają jako mniej wspierającą, aprobującą czy optymistyczną, a zarazem bardziej autorytatywną i defensywną (Henry i in., 1993, s. 438-439).

Diagnoza interpretatywna ${ }^{2}$. Odmienny sposób rozpoznawania problemów proponowany jest przez zwolenników podejścia interpretatywnego, do któ-

2 Warto odnotować, że w większości opracowań zagranicznych w kontekście podejść interpretatywnych unika się stosowania terminu „diagnoza”, który kojarzony jest z ujęciem normatywnym 
rego zaliczyć można m.in. krytyczną pracę socjalną (Healy, 2001; Fook, 2003; Dominelli, 2004; Lundy, 2004), podejście oparte na praktyce (praxis-based approach) (Petersen, Olsson, 2015) oraz podejście feministyczne (Tyson, 1992; Fawcett, Featherstone, Fook, Rossiter, 2000; Bell, 2012). W tej optyce marginalizowanie znaczenia indywidualnych doświadczeń na rzecz ulepszania narzędzi pomiaru i procedur będących konsekwencjami postawionej diagnozy uznawane jest za działania depersonalizujące ludzi, którym udzielana jest pomoc. Jak zauważa Karen Bell (2012), sposób postępowania, w którym negowane jest subiektywne doświadczenie człowieka, w rzeczy samej go depersonalizuje. W tej logice myślenia człowiek zamiast być aktywnie działającą jednostką w procesie rozwiązywania problemu zaczyna być postrzegany (przez profesjonalistów) jako przedmiot czyjegoś działania, któremu powinien się podporządkować (Bell, 2012, s. 413).

Zwolennicy podejścia interpretatywnego $\mathrm{w}$ pracy socjalnej zamiast wyjaśnień czy też oceny diagnozowanego zjawiska proponują zrozumienie logiki, która kryje się za działaniami klienta. Jak zauważa Mariusz Granosik, zarysowany w ten sposób cel diagnozy postuluje działanie „trochę wbrew formalnym oczekiwaniom, nakazującym przede wszystkim ewidencjonować definiowany statycznie problem klienta" (Granosik, 2013a, s. 9). W optyce tej reprezentant społecznej profesji koncentruje się nad:

(...) kwestiami epistemologicznymi, czyli pytaniami, jak klient jest postrzegany, jak sam siebie postrzega, jak jest społecznie wytwarzany jego problem i jakie uwarunkowania mają w tym udział. Innymi słowy, praca socjalna nie polega na ustaleniu, że klient jest np. długotrwale bezrobotny, a następnie znalezieniu mu pracy, ale na zrozumieniu procesu dezaktywacji zawodowej i podjęciu działań, które najlepiej będą równoważyć interes klienta i społeczeństwa. (Granosik, 2013a, s. 9)

W tej perspektywie proces diagnostyczny oznacza dążenie do zrozumienia człowieka w konkretnym układzie społecznym. Podobnie o celu diagnozy w pracy socjalnej piszą Malcolm Williams i Brian Cheal (2002) oraz Joel Blau (2017). Autorzy podkreślają, że trudno jest zrozumieć problemy (np. osób bezdomnych) na podstawie danych statystycznych czy charakterystyki demograficznej. Oczywiste jest jednak, że: „(...) jeżeli pracownik socjalny chce pomóc osobom w trudnej sytuacji życiowej (poor people), niezbędne jest zdobycie wiedzy na ich temat" (Blau, 2017, s. 83).

czy wręcz medycznym. Pojęcie to jest zastępowane takimi określeniami, jak: „ocena” (assessment), „,analiza” (Fallanalyse). W naszym zespole badawczym, zajmującym się tym zagadnieniem, uznaliśmy jednak, że pojęcie „diagnoza” najlepiej będzie oddawać sens i znaczenie tego działania. Ponadto dzięki pozostawieniu terminu ,diagnoza” zakładamy, że stanie się on lepiej rozpoznawalny zarówno wśród badaczy, jak i praktyków. 


\section{METODOLOGIA DIAGNOSTYKI INTERPRETATYWNEJ}

Sposób rozpoznawania problemów przez interpretatywnie zorientowanych diagnostów wymaga użycia odmiennej metodologii niż w tradycyjnej diagnozie społeczno-pedagogicznej. Ogólne założenia paradygmatu interpretatywnego, które zostały już opisane w różnych publikacjach (zob. np. Czyżewski, 1984; Granosik, 2006), przekładają się na wiele konkretnych metod, które w znacznej części stały się inspiracją do konstruowania strategii diagnostycznych (Riemann, 2009). Wśród nich wymienić można diagnostykę zorientowaną biograficznie (np. wywiad autobiograficzny - Riemann, Schütze, 1992; Schütze, 2008a, 2008b, 2012), etnograficznie (np. teoria ugruntowana - Charmaz, 2009; Glaser, Strauss, 2009; badanie-działanie - Gulczyńska, 2013), konwersacyjnie (np. analiza konwersacyjna - Garfinkel, 2007; Rancew-Sikora, 2007; Granosik, 2013b) czy partycypacyjnie (Beresford, 2019; Granosik, Gulczyńska, Kostrzyńska, Littlechild, 2019).

Odmienność tego sposobu rozpoznawania problemów polega na „braku normatywnych ram, które można byłoby przyłożyć do badanego przypadku, by »obiektywnie« określić, na ile odbiega on od społecznie definiowanej normalności” (Granosik, 2013a, s. 17), konsekwencją czego jest niemożność wykonania jakiegokolwiek pomiaru. W diagnozie interpretatywnej podkreśla się kwestię rozumienia przypadku w odniesieniu do lokalnego kontekstu społecznego. W miejsce statycznej kwalifikacji problemu do określonej kategorii (jak np. bezrobocie, niewydolność wychowawcza, bezdomność itd.) proponuje się opis procesu powstawania problemu wraz z analizą uwarunkowań na poziomie mikro, mezo i makro. Warto dodać, że proces diagnozowania interpretatywnego zwykle wymaga nieco więcej czasu, w związku z czym konieczna jest równoległa realizacja kilku czynności, np. diagnozowania i działania, przy czym samo działanie (jak np. diagnoza w wariancie badanie-działanie) może być jednocześnie elementem procesu diagnostycznego i oddziaływania.

\section{DIAGNOZA INTERPRETATYWNA W POLU PRAKTYKI PRACY SOCJALNEJ}

Efekty diagnozy dokonanej w ujęciu interpretatywnym przekładają się na praktykę pracy socjalnej/społecznej. Rezultatem normatywnie zorientowanej diagnozy powinna być możliwie ,zobiektywizowana analiza środowiska, w którym jednostka funkcjonuje [a następnie jej zestawienie - A.J.] z obrazem wzorcowego, idealnego środowiska wychowawczego, co umożliwia wskazanie obszarów odbiegających od wzorca" (Granosik, 2013a, s. 16). W tym ujęciu głównym celem działań pracowników socjalnych jest ,pomoc jednostkom w adaptacji i radzeniu sobie z określonymi sytuacjami społecznymi” (Fook, 1993, za: Gulczyńska, 2006, s. 398). Cel główny dookreślany jest przez cele szczegółowe, które zazwyczaj koncentrują się na takich zabiegach, jak: profilaktyka, kompensacja, ratownictwo itd. 
$\mathrm{Z}$ odmiennym modelem praktyki mamy do czynienia w momencie przyjęcia ujęcia interpretatywnego. Rekonstrukcja „uwarunkowań społecznych jednostki tożsama będzie z rozpoznaniem jej świata przeżywanego" (Granosik, 2013a, s. 16). Uznaje się bowiem, że pożądany efekt oddziaływania ma szansę zaistnieć, jeśli zostanie ono zaplanowane $z$ uwzględnieniem elementów znaczących $i$ istotnych z punktu widzenia osoby potrzebującej pomocy. Wiedzę o komponentach świata przeżywanego jednostki pracownik socjalny może wykorzystać na kilka sposobów. Po pierwsze, może starać się przyjąć rolę profesjonalnego operatora trajektorii bądź opiekuna biografii (Riemann, Schütze, 1992), wiedząc, które doświadczenia klienta były dla niego szczególnie trudne czy traumatyczne i w pewnym stopniu nadal są przez niego przeżywane bądź skutki ich wydarzenia obserwowane są w teraźniejszości (biograficznie nie zostały przepracowane przez jednostkę). W ramach przyjęcia roli profesjonalnego operatora trajektorii pracownik podejmuje:

(...) pracę nad spowolnieniem, zahamowaniem, a nawet nad zatrzymaniem dynamiki trajektorii (...) w wypadkach, w których wydaje się to rozsądne i osiągalne, może podjąć systematyczny wysiłek zmierzający do wyeliminowania potencjału trajektoryjnego poprzez całkowitą reorganizację sytuacji życiowej, która obejmuje usilną pracę biograficzną nad własnym rozwojem osobowym. (Riemann, Schütze, 1992, s. 410)

Po drugie, pracownik socjalny może wystąpić w roli mediatora, którego zadaniem byłoby doprowadzenie do dialogu czy udrożnienie komunikacji. Problemy klientów są obecne w wymiarze społecznym, co oznacza, że w danym społeczeństwie problemowi przypisywane jest określone znaczenie (uzależnione od tradycji, kultury, istniejących stereotypów, wiedzy), które oddziałuje na jednostki i ich sposób myślenia o nim. W wielu przypadkach problemy, z którymi borykają się klienci, postrzegane są negatywnie, a osoby ich doświadczające społecznie uznawane są za winne swojej sytuacji (np. bezdomni), czego częstą konsekwencją jest niechęć, brak komunikacji czy wykluczanie takich osób. W takich okolicznościach przynajmniej z kilku powodów powinna być przez pracownika socjalnego zainicjowana mediacja. Jednym z najważniejszych wydaje się być dążenie do polepszenia jakości życia jednostki w wielu wymiarach (jednostkowym, społecznym). Trudno jednak wyobrazić sobie jakąkolwiek poprawę bez istotnej zmiany atmosfery w środowisku klienta (np. rodzinnym, sąsiedzkim). Jako przykład może posłużyć sytuacja osób z zaburzeniem psychicznym, którym powszechnie przypisuje się skłonność do zachowań agresywnych, nieobliczalność itd. Większość osób nie chce utrzymywać z takimi ludźmi bliższych relacji. Próba mediacji podjęta przez pracownika socjalnego w miejscu zamieszkania takiej osoby mogłaby zmienić postawę innych wobec problemu na bardziej akceptującą bądź rozumiejącą. 
Po trzecie, pracownik socjalny/społeczny może wystąpić w roli rzecznika. Osoba, która dokonała diagnozy interpretatywnej skoncentrowanej wokół kwestii rozumienia świata przeżywanego klienta, wydaje się najlepszym reprezentantem interesów osób doświadczających określony typ problemu. Głównym celem stosowania rzecznictwa jest ,pomniejszanie efektów stygmatyzacji, przejawów dyskryminacji i tłumaczenia logiki postępowania »większości« przedstawicielom mniejszości [ale także próby tłumaczenia logiki postępowania mniejszości w celu zaistnienia ich głosu w dyskursie - A.J.] narażonym na restrykcje w przypadku braków w wymaganym stopniu jej opanowania” (Gulczyńska, 2006, s. 407).

Warto również wspomnieć, że orientacja działania w ujęciu interpretatywnym skoncentrowana jest wokół poszukiwania dróg nowego porządku społecznego, który zmieniłby równowagę pomiędzy większością a mniejszością, nie zaś - jak ma to miejsce w pracy socjalnej w ujęciu normatywnym - na poszukiwaniu możliwości włączenia jednostek do reszty społeczeństwa.

\section{PRZYKŁAD DIAGNOZY W UJĘCIU NORMATYWNYM I INTERPRETATYWNYM}

Poniższa diagnoza ${ }^{3}$ została wykonana przez studentkę pedagogiki społecznej, Aleksandrę Sobańską, w ramach przedmiotu elementy diagnostyki interpretatywnej w semestrze letnim 2015/2016.

Opis przypadku. Studentka przez około 6 miesięcy pracowała z chłopcem $\mathrm{w}$ wieku lat 16 . Praca $\mathrm{z}$ chłopcem związana była z realizowanymi przez nią w ramach cyklu studiów praktykami śródrocznymi. Chłopiec został jej przydzielony przez pracownika socjalnego i asystenta rodzinnego, którzy od jakiegoś czasu współpracowali z rodziną. Pretekstem do pojawienia się studentki w środowisku były problemy szkolne Krzyśka ${ }^{4}$. Chłopiec nie został promowany do następnej klasy z uwagi na zaniedbywanie obowiązków szkolnych. W tym czasie chłopiec był uczniem gimnazjum. Poza pomocą w lekcjach zadaniem studentki było dokonanie diagnozy. W ramach tego zadania studentka zdecydowała się przeprowadzić z chłopcem wywiad autobiograficzny, w trakcie którego dowiedziała się następujących rzeczy. Krzysiek wychowuje się od dziecka z dziadkami. Matka chłopca urodziła go w wieku 16 lat, poza nim ma jeszcze czwórkę młodszych dzieci. Ojciec Krzyśka nadużywa alkoholu. Chłopak mówi, że nienawidzi ojca, ponieważ uważa, że jest przez niego gorzej traktowany niż reszta rodzeństwa. Według Krzyśka ojciec zamiast na jedzenie dla swoich dzieci pieniądze wydaje

3 Serdecznie dziękuję A. Sobańskiej, niegdyś mojej studentce, dzisiaj wspaniałej aktywistce walczącej o równość i wolność dla każdego, za wyrażenie zgody na wykorzystanie jej materiału przy tworzeniu tego podpunktu.

4 Imię chłopca zostało zmienione. 
na alkohol, po spożyciu którego zaczyna być chorobliwie zazdrosny o żonę, staje się agresywny i bije ją.

Pasją chłopca jest kibicowanie, do którego zachęcił go dziadek - zagorzały kibic piłkarski. Dziadek pierwszy raz zabrał swojego wnuczka na mecz, gdy ten miał 5 lat. Od tamtego czasu Krzysiek interesuje się piłką nożną. W dzieciństwie chłopak miał przyjaciela, również fana piłkarskiego, tylko innego klubu5. W ówczesnym czasie Krzyśkowi to nie przeszkadzało. Wspólnie z przyjacielem założyli nawet podwórkowy klub piłkarski i organizowali mecze dla swoich rówieśników. Niestety, gra w piłkę przeszkadzała sąsiadom, w tym zwłaszcza jednej pani, która poprosiła administratora bloku o przywieszenie tabliczki zakazującej gry w piłkę. Krzysiek wspomina komentarz tej sąsiadki, która powiedziała, że po takich rodzicach to nic dobrego ze mnie nie wyrośnie. Mama urodziła mnie jak miała 16 lat, a ojciec porobil kilka awantur po alkoholu i nachodził dziadków, jak mama tu przychodziła. Sasiadka uznała mnie za jakiegoś ,,dziedzica patoli”, więc próbowatem wysadzić tabliczkę w powietrze za pomoca petard, ale bez efektów ${ }^{6}$.

Jak mówi Krzysiek, jego życie uległo zmianie, kiedy przeprowadził się na inne osiedle, na którym większość kibiców była fanami przeciwnej drużyny piłkarskiej. Tamci, wiedząc, że Krzysiek kibicuje „wrogiemu” im klubowi, zaczepiali go, kilka razy został nawet uderzony kamieniem. Początkowo Krzysiek starał się to ignorować, ale jego poczucie bezpieczeństwa w tym miejscu z dnia na dzień stawało się coraz mniejsze. Dlatego też zapisał się na zajęcia MMA, żeby - jak sam mówi - nie być ofiara ulicy. Na zajęciach poznał starszych kolegów z Obozu Narodowo-Radykalnego (ONR) i jednocześnie kibiców klubu piłkarskiego, któremu sam kibicował. Wspólnie z nowymi znajomymi zaczął jeździć na mecze.

Istotnym wydarzeniem w życiu Krzyśka było „wydanie” go kibicom przeciwnej drużyny przez jego przyjaciela z dzieciństwa (tego samego, co organizował z nim mecze dla rówieśników). Chłopak został przez nich pobity. W ramach zemsty Krzysiek pobił swojego dawnego przyjaciela. Przez to zdarzenie Krzysiek miał rozprawę w sądzie, jej efektem było pouczenie. Ponadto, jak mówi Krzysiek, od tego momentu jego sytuacja w szkole uległa znacznemu pogorszeniu. Chłopak skonfliktował się z jednym z nauczycieli, przez którego - jak twierdzi - zaczął zaniedbywać obowiązki szkolne, a w konsekwencji nie dostał promocji do następnej klasy. Sam Krzysiek mówi o tym w ten sposób: Doszło do spotkania jednego z prowodyrów nienawiści na mnie, którym - jak się okazało - byt mój najlepszy kolega, z którym zakładałem klub osiedlowy. Dostał po pysku, donióst na mnie mamie i zaczęła się pierwsza moja sprawa sądowa zakończona pouczeniem. W szkole też się wtedy dowiedzieli i od tego czasu moje stosunki z ,kadra pato-

5 W mieście, w którym mieszka chłopiec, są dwa kluby piłkarskie, których kibice od lat są skonfliktowani.

6 Wypowiedzi chłopca zostały zapisane kursywą. 
logiczna" ze zlych stały się beznadziejne. W sumie to się tym nie przejmowatem. Rodzina jest najważniejsza. W sensie rodzina z trybun.

Diagnoza normatywna ${ }^{8}$. Dokonując diagnozy w ujęciu normatywnym, studentka zwróciła uwagę na niewydolność wychowawczą dziadków oraz rodziców Krzyśka. Dziadkowie, a tym bardziej rodzice, w opinii studentki nie spełnili się $\mathrm{w}$ pełnieniu tych ról. Rodzice - z uwagi na problemy z alkoholem, stosowanie przemocy, a także wielodzietność - nie byli w stanie w sposób właściwy zając się chłopcem. Nie czuł on ze strony rodziców wsparcia, był bardzo krytyczny wobec ich zachowania, miał do nich żal o wiele rzeczy. W związku z powyższym studentka więzi Krzysztofa z rodzicami sklasyfikowała jako zaburzone. Z kolei dziadkowie, mimo że Krzysiek czuł do nich wdzięczność za opiekę, nie byli w stanie uchronić chłopca od „złego towarzystwa” $\mathrm{i}$ jego wpływu na niego. Dziadkowie w którymś momencie przestali być autorytetem dla dorastającego chłopaka, a ważniejsi i bardziej wpływowi od nich stali się koledzy z ONR.

Za znaczące do diagnozy problemu w ujęciu normatywnym studentka uznała również agresywne zachowania Krzysztofa (np. w stosunku do dawnego przyjaciela czy nauczycielki), akty wandalizmu (podłożenie petardy pod znak „zakaz gry w piłkę"), kłopoty wychowawcze w środowisku rodzinnym i szkolnym (brak kontroli, aroganckie zachowanie w stosunku do nauczycieli, brak pozytywnych efektów rozmów z chłopcem) oraz niepowodzenia szkolne (brak promocji do następnej klasy, zaniedbywanie obowiązków szkolnych).

Z powyższej klasyfikacji problemów zostały wyróżnione trzy obszary działania dla pedagoga społecznego, psychologa, pracownika socjalnego, wychowawcy czy terapeuty:

1. Praca $\mathrm{z}$ jednostką. $\mathrm{W}$ tym zakresie zaproponowano: pomoc $\mathrm{w}$ nadrobieniu materiału szkolnego; zajęcia korekcyjno-wychowawcze, których dodatkowym celem byłoby „odciągnięcie” chłopca od negatywnych wpływów kolegów; minimalizację skutków negatywnej socjalizacji (negative learning from the past); trening umiejętności interpersonalnych; pomoc psychologiczną; pomoc jednostce $\mathrm{w}$ adaptacji i radzeniu sobie w określonych sytuacjach społecznych. W przypadku braku pozytywnych efektów powyższych czynności zasugerowane zostały do podjęcia radykalne formy działania rozumiane jako ratownictwo, połączone z profilaktyką hamującą. W tym kontekście ozna-

\footnotetext{
7 Specyficzny dla Krzysztofa sposób nazywania kadry pedagogicznej.

8 Warto w tym miejscu powtórzyć, że tradycyjną diagnozę studentka robiła w semestrze poprzedzającym kurs z diagnostyki interpretatywnej. Pani Aleksandra nie posiadała wówczas wywiadu autobiograficznego $\mathrm{z}$ chłopcem (który został zrobiony dopiero $\mathrm{w}$ ramach przedmiotu z zakresu diagnozy interpretatywnej), a informacje o chłopcu czerpała przede wszystkim z rozmów z pracownikiem socjalnym, asystentem rodziny, dziadkami, samym chłopcem oraz z obserwacji jego zachowania.
}

9 Kolegów z ONR. 
cza ono drastyczne oderwanie chłopca od negatywnego środowiska kolegów z ONR, z którymi kontakt został uznany za ryzykowny i zagrażający popełnieniem przez Krzysztofa czynów zabronionych (jak np. naruszenie nietykalności cielesnej, akty wandalizmu). W ramach tego działania zasugerowano kwalifikację chłopca do ośrodka socjoterapii bądź wychowawczego.

2. W środowisku rodzinnym: terapia rodzinna (w tym zwłaszcza pomiędzy Krzyśkiem a rodzicami); praca nad relacjami w rodzinie; terapia uzależnień (dla ojca Krzyśka); wsparcie socjalno-finansowe; wsparcie społeczno-wychowawcze dla Krzyśka, dziadków i rodziców.

3. W środowisku szkolnym: pomoc dla Krzysztofa w przyswojeniu materiału szkolnego; umożliwienie jednostkowego przystosowania i radzenia sobie w określonych sytuacjach społecznych; pomoc w przyswojeniu norm i ról społecznych.

Diagnoza interpretatywna nie bagatelizuje żadnego efektu analizy normatywnej. Akty wandalizmu i przemocy fizycznej czy słownej wobec rówieśników i nauczycieli traktowane są w ten sam sposób jak w ujęciu normatywnym. Różnica polega na tym, że zamiast skupić się na samym zdarzeniu i tym samym na kategoryzacji chłopca jako agresywnego i niedostosowanego społecznie, interpretatywnie zorientowany diagnosta stara się zrozumieć, dlaczego takie wydarzenie miało miejsce i co do niego doprowadziło. W miejsce poszukiwania „obiektywnych przesłanek” (w tym wypadku: rodzina wieloproblemowa, wielodzietność, niewydolność wychowawcza, alkohol, przemoc) diagnosta interpretatywny stara się znaleźć odpowiedź na pytanie: Jakie znaczenie dla diagnozowanej jednostki mają powyższe elementy? Z wypowiedzi chłopca można wywnioskować, że najbardziej bolesny dla niego był fakt, że inni patrzyli i interpretowali go przez pryzmat jego rodziny, o czym może świadczyć przytoczony już fragment jego wypowiedzi: Pamiętam jak dziś jak powiedziata mi, że po takich rodzicach to nic dobrego ze mnie nie wyrośnie. Mama urodziła mnie jak miała 16 lat, a ojciec porobit kilka awantur po alkoholu i nachodzit dziadków, jak mama tu przychodzita. Sasiadka uznata mnie za jakiegoś ,,dziedzica patoli”, więc próbowatem wysadzić tabliczke w powietrze za pomoca petard, ale bez efektów.

Studentka, diagnozując powyższą wypowiedź, zauważyła znaczące podobieństwo pomiędzy opisywanym w niej zjawiskiem a koncepcją piętna Ervina Goffmana (2005). Piętno Krzysztofa było piętnem oddziedziczonym po rodzicach. Wskutek tego dziedzictwa chłopcu została nadana przez sąsiadów dyskredytująca pozorna tożsamość społeczna (chłopaka trudnego, agresywnego i pewnie pijaka). Pozorna tożsamość społeczna reprezentuje pożądane wzory zachowania jednostki przypisane jej warunkowo z perspektywy przeszłości tudzież z perspektywy zachowania rodziców. Chłopak, mimo że nie robił w tamtym czasie niczego złego (wręcz przeciwnie - zajmował się aktywnością fizyczną, a nawet animacją życia podwórkowego poprzez organizowanie meczy piłkarskich), został oceniony przez pryzmat 
znanych w tamtejszej społeczności sąsiedzkiej jego problemów rodzinnych. Izabela Ślęzak zwraca uwagę na skomplikowaną sytuację nosiciela piętna, pisząc:

(...) z jednej strony ,,jego najgłębsze uczucia” podpowiadają mu, że powinien być traktowany w taki sam sposób jak inni, pozbawieni danego atrybutu. Jednocześnie zinternalizowane normy społeczne sprawiają, że zdaje on sobie sprawę, iż nie jest akceptowany przez innych. Skutkiem tej sytuacji często jest wstyd, odczuwany szczególnie silnie w interakcjach z „normalsami” ${ }^{0}$. (Ślęzak, 2013, s. 155)

Jak zauważyła studentka: „,...) stosunek, jaki normalsi mają do osoby napiętnowanej, powoduje (często nieświadome) zmniejszanie jej życiowych szans. Nauczycielki w szkole miały wyrobioną opinię o Krzyśku - już od samego początku traktowały go jako lenia, który w głowie ma tylko mecze, bójki z innymi kibicami i jedyne, co potrafi, to sprawiać problemy. Uznały, że powodem takiego zachowania jest brak wychowania i jego trudny charakter" (fragment niepublikowanej pracy zaliczeniowej A. Sobańskiej). Pani Sobańska zwróciła również uwagę, iż Krzysiek, który nie zaznał wsparcia od rodziny, dostał je od kolegów z ONR i to oni stali się dla niego wzorem. Sam Krzysiek mówił o nich w ten sposób: Rodzina jest najważniejsza. W sensie rodzina z trybun. Nigdy się na nich nie zawiodtem, w przeciwieństwie do matki i ojca. Olałem naukę, bo po co mam się uczyć, jak i tak kadra patologiczna nie przestanie mnie gnębić. Dla nich i tak jestem nikim, a tak naprawdę to ta banda idiotów jest głupsza ode mnie. Mam starszego kumpla z ONR-u i on poszedt uczyć się do hufca i chyba sam tam pójdę.

Studentka w swojej pracy przyznała się, że początkowo trudno jej było oddzielić to, co robi chłopak w swoim wolnym czasie, jak się zachowuje i wygląda od tego, kim jest. Praca z nim zaskoczyła ją pod wieloma względami. Na początku myślała, że ma do czynienia „z typowym kibolem”, czyli - jak podpowiada stereotyp - z mało inteligentnym, agresywnym człowiekiem. Tymczasem Krzysiek okazał się bystrym i wrażliwym chłopakiem, z którym można było porozmawiać na każdy temat.

Skoncentrowanie uwagi w diagnozie interpretatywnej na odmiennych niż $\mathrm{w}$ diagnozie normatywnej kwestiach zmusiło diagnostę do zmiany orientacji działania. W tak zarysowanej sytuacji na plan pierwszy wysuwa się praca ze społecznością (kadrą nauczycieli, sąsiadami), która w pewnym sensie przyczyniła się do eskalacji problemów chłopca (np. poprzez przypisanie mu dyskredytującej pozornej tożsamości społecznej i orientację działania bazującą na negatywnej kategoryzacji Krzyśka, a także przez nieudzielenie mu właściwego wsparcia). Praca z chłopcem w tym ujęciu polegałaby na minimalizowaniu skutków zinternalizowanego przez niego piętna, wzmocnieniu jego poczucia wartości oraz poczucia

10 Termin „normalsi” użyty za E. Goffmanem (2005, s. 38). 
zdolności do działania (empowerment). Zamiast na deficytach chłopca można pracować na jego siłach (koncepcja sił jednostkowych - Radlińska, 1935; podejście skoncentrowane na siłach, strength-based approach - zob. np. Reynolds, 1939). Chłopiec ma unikalne cechy: doskonałą znajomość zasad gry w piłkę nożną; zdolności organizacyjne (organizacja gier podwórkowych); prawdopodobnie też cechy przywódcze (leadership), które można wykorzystać jako bazę do orientowania działań społeczno-pedagogicznych (np. włączenie chłopca do życia szkolnego poprzez wykorzystanie opisanego potencjału). Trudno ocenić, na ile możliwe jest w danym momencie przekonanie chłopca o odłączeniu od grupy kibiców, można jednak próbować minimalizować ich wpływ poprzez znaczących innych (np. dziadków, ewentualnie wychowawcę, pedagoga, pracownika socjalnego - osoby, którym Krzysiek zaufa).

\section{ZAKOŃCZENIE}

Diagnostyka interpretatywna w mojej opinii jest atrakcyjną alternatywą dla tradycyjnych metod rozpoznawania problemów w pracy socjalnej. Nie oznacza to jednak, że nie dostrzegam pewnych trudności w jej aplikacji do obszaru działania. W tym miejscu przedstawię tylko niektóre $\mathrm{z}$ nich. Pierwsze pojawiają się już w wymiarze teoretycznym, którego konsekwencją jest system edukacyjny. Program kształcenia przyszłych pedagogów społecznych czy pracowników socjalnych jest tak skonstruowany, aby przygotować studenta do mierzenia oraz ścisłego, obiektywnego opisu zjawiska. Interpretatywnie zorientowany praktyk potrzebuje czasu do poznania i zrozumienia środowiska, w którym podejmowana jest interwencja, a efektów takiej pracy nie da się przedstawić w odniesieniu do istniejących norm (np. zachowania, rozwoju itd.). Kolejne trudności pojawiają się w sferze praktycznej. Pedagogika społeczna czy praca socjalna jest niejako z założenia, w zakresie praktycznym, nauką normatywną, ponieważ wskazuje na to co dobre, a co złe i to co złe należy za pośrednictwem działań zmienić, eliminować bądź poprawiać. Ten sposób uprawiania praktyki dla osób podejmujących próbę diagnozowania problemu w ujęciu interpretatywnym jest niezwykle kłopotliwy do zmiany. Normatywne schematy myślenia i orientowane w odniesieniu do nich działania nazbyt często pojawiają się w ,studenckich diagnozach”. Ma to pewnie związek z potrzebą praktyków i praktyki do posiadania możliwie „prostych” systemów wartościowania, które umożliwiają im podjęcie interwencji i dokonanie jej oceny. Ostatnią z trudności zaobserwować można w wymiarze organizacyjnym. Związane jest to np. z nienarracyjną strukturą dokumentarną. Dokumenty w niemal każdej instytucji dopasowane są do wymogów prawno-instytucjonalnych, a nie do klienta/ wychowanka/ pensjonariusza. Ponadto poważną przeszkodą do aplikacji podejścia interpretatywnego w obszarze pracy socjalnej jest wspomniany już czas, który jest potrzebny na dokonanie tego rodzaju diagnozy i późniejszej 
orientacji działania. W wielu instytucjach pomocy społecznej po prostu nie ma na to miejsca - zbyt wielu klientów, zbyt mało czasu.

Wspomniane powyżej trudności nie oznaczają jednak całkowitej niemożliwości stosowania diagnostyki interpretatywnej w polu pracy socjalnej. Uważam, że ten rodzaj rozpoznawania problemów w szczególności ma szansę na powodzenie np. w takich instytucjach, jak: środowiskowy dom samopomocy, świetlice środowiskowe, szkoła (pedagog szkolny), ośrodek socjoterapii, ośrodek wychowawczy itp., gdzie praktyk ma możliwość poznawania klienta/ wychowanka/ pensjonariusza przez dłuższy czas i tym samym może go obserwować w różnych sytuacjach.

\section{BIBLIOGRAFIA}

Bell, K. (2012). Towards a post-conventional philosophical base for social work. British Journal of Social, 42(3), 408-423. DOI: https://doi.org/10.1093/bjsw/bcr073

Beresford, P. (2019). Radicalising Social Work: Involving Everyone; Including All Our Knowledges. W: M. Granosik, A. Gulczyńska, M. Kostrzyńska, B. Littlechild (eds.), Participatory Social Work: Research, Practice, Education (s. 325-339). Łódź-Kraków: Wydawnictwo UŁ, Wydawnictwo UJ.

Blau, J. (2017) Science as a Strategy for Social Work. Journal of Progressive Human Services, 28(2), 73-90. DOI: https://doi.org/10.1080/10428232.2017.1310543

Charmaz, K. (2009). Teoria ugruntowana. Praktyczny przewodnik po analizie jakościowej. Warszawa: PWN.

Czyżewski, M. (1984). Socjolog i życie potoczne. Studium z etnometodologii i współczesnej socjologii interakcji. Acta Universitatis Lodziensis. Folia Sociologica, (8).

Dominelli, L. (2004). New Directions for Social Work: Interdependence, Reciprocity, Citizenship, and Social Justice. Malden: Polity Press.

Fawcett, B., Featherstone, B., Fook, J., Rossiter, A. (2000). Practice and Research in Social Work: Postmodern Feminist Perspectives. New York: Routledge.

Fook, J. (1993). Radical Casework: A Theory of Practice. St. Leonards: Allwn \& Uniwin.

Fook, J. (2003). Critical social work: The current issues. Qualitative Social Work, 2(2), 123-130. DOI: https://doi.org/10.1177/1473325003002002001

Garfinkel, H. (2007). Studia z etnometodologii. Warszawa: PWN.

Glaser, G.B., Strauss, A.L. (2009). Odkrywanie teorii ugruntowanej. Kraków: Wydawnictwo Nomos. Goffman, E. (2005). Piętno. Rozważania o zranionej tożsamości. Gdańsk: GWP.

Granosik, M. (2006). Związki z socjologią interpretatywną. W: E. Marynowicz-Hetka (red.), Pedagogika społeczna. Podręcznik akademicki (T. 1; s. 171-183). Warszawa: PWN.

Granosik, M. (2013a). Praca socjalna w perspektywie interpretatywnej: teoria, diagnoza, działanie. W: A. Skowrońska (red.), Nowe ujęcia znanych problemów społecznych (s. 7-21). Warszawa: Koordynacja na Rzecz Aktywnej Integracji.

Granosik, M. (2013b). Praca socjalna. Analiza instytucjonalna z perspektywy konwersacyjnej. Łódź: Wydawnictwo UŁ.

Granosik, M., Gulczyńska, A., Kostrzyńska, M., Littlechild, B. (eds.). (2019). Participatory Social Work: Research, Practice, Education. Łódź-Kraków: Wydawnictwo UŁ, Wydawnictwo UJ.

Gulczyńska, A. (2006). Model radykalnej pracy socjalnej - analiza na podstawie badań nad procesem wrastania społecznego nastoletniej młodzieży w wielkomiejskim środowisku życia. W: E. Marynowicz-Hetka (red.), Pedagogika społeczna. Podręcznik akademicki (T. 1; s. 397410). Warszawa: PWN. 
Gulczyńska, A. (2013). „Chłopaki z dzielnicy”. Studium społeczno-pedagogiczne z perspektywy interakcyjnej. Łódź: Wydawnictwo UŁ.

Healy, K. (2001). Reinventing critical social work: Challenges from practice, context, and postmodernism. Critical Social Work, 2(1), 1-13.

Henry, W.P., Strupp, H.H., Butler, S.F., Schacht, T.E., Binder, J.L. (1993). Effects of training in time-limited dynamic psychotherapy: Changes in therapist behavior. Counseling and Clinical Psychology, 61(3), 434-440. DOI: https://doi.org/10.1037/0022-006X.61.3.434

Jarosz, E. (2001). Wybrane obszary diagnozowania pedagogicznego. Katowice: Wydawnictwo UŚ.

Jarosz, E., Wysocka, E. (2006). Diagnoza psychopedagogiczna. Podstawowe problemy i rozwiazania. Warszawa: Wydawnictwo Akademickie „Żak”.

Joachimowska, M. (2012). Diagnostyka społeczna. Wymiar teoretyczny i praktyczny. Bydgoszcz: Wydawnictwo Edukacyjne.

Kamiński, A. (1974). Funkcje pedagogiki społecznej. Warszawa: PWN.

Lepalczyk, I., Badura, J. (1987). Elementy diagnostyki pedagogicznej. Warszawa: PWN.

Lundy, C. (2004). Social Work and Social Justice: A Structural Approach to Practice. Peterborough: Canada Broadview.

Marynowicz-Hetka, E. (1987). Diagnostyka pedagogiczna w pracy socjalno-wychowawczej. W: I. Lepalczyk, J. Badura (red.), Elementy diagnostyki pedagogicznej (s. 46-67). Warszawa: PWN.

Marynowicz-Hetka, E. (2006). Pedagogika społeczna. Podręcznik akademicki (T. 1). Warszawa: PWN.

Mazurkiewicz, E. (1987). Teoretyczne podstawy diagnostyki pedagogicznej. W: I. Lepalczyk, J. Badura (red.), Elementy diagnostyki pedagogicznej (s. 49-68). Warszawa: PWN.

Petersen, A.C., Olsson, J.I. (2015). Calling evidence-based practice into question: Acknowledging phronetic knowledge in social work. British Journal of Social Work, 45(5), 1581-1597.

DOI: https://doi.org/10.1093/bjsw/bcu020

Radlińska, H. (1935). Stosunek wychowawcy do środowiska społecznego. Szkice z pedagogiki spotecznej. Warszawa: Nasza Księgarnia.

Rancew-Sikora, D. (2007). Analiza konwersacyjna jako metoda badania rozmów codziennych. Warszawa: Wydawnictwo Trio.

Reynolds, B. (1939). Re-thinking Social Case Work. New York: Social Work Today.

Richmond, M. (1917). Social Diagnosis. New York: Russel Sage Foundation.

Riemann, G. (2009). Der Beitrag interaktionistischer Fallanalysen professionellen. Handelns zur sozialwissenschaftlichen Fundierung und Selbstkritik der Sozialen Arbeit. W: R. Becker-Lenz, S. Busse, G. Ehlert, S. Müller-Hermann (Hrsg.), Professionalität in der Sozialen Arbeit. Standpunkte, Kontroversen, Perspektive (s. 287-318). Wiesbaden: Springer VS.

Riemann, G., Schütze, F. (1992). „Trajektoria” jako podstawowa koncepcja teoretyczna w analizach cierpienia i bezładnych procesów społecznych. Kultura i Społeczeństwo, (2), 89-111.

Schütze, F. (2008a) Biography Analysis on the Empirical Base of the Autobiographical Narratives: How to Analyse Autobiographical Narrative Interviews (Part I). INVITE - Biographical Counselling in Rehabilitative Vocational Training. Further Educational Curriculum. EU Leonardo da Vinci Programme.

Schütze, F. (2008b). Biography Analysis on the Empirical Base of the Autobiographical Narratives: How to Analyse Autobiographical Narrative Interviews (Part II). INVITE - Biographical Counselling in Rehabilitative Vocational Training. Further Educational Curriculum. EU Leonardo da Vinci Programme.

Schütze, F. (2012). Analiza biograficzna ugruntowana empirycznie w autobiograficznym wywiadzie narracyjnym. Jak analizować autobiograficzne wywiady narracyjne W: K. Kaźmierska (red.), Metoda biograficzna w socjologii. Antologia tekstów (s. 141-278). Kraków: Wydawnictwo Nomos. 
Soulet, M.H. (1996). Działanie społeczne i jego wymiar pedagogiczny na przykładzie pracy socjalnej z rodziną. W: E. Marynowicz-Hetka, J. Piekarski, D. Urbaniak-Zając (red.), Pedagogika społeczna i praca socjalna. Przeglad stanowisk i komentarze (s. 98-120). Warszawa: Wydawnictwo „Interart”.

Ślęzak, I. (2013). Refleksje nad zagadnieniem piętna w relacjach badacza i badanych na podstawie wywiadów z kobietami świadczącymi usługi seksualne. Nauka i Szkolnictwo Wyższe, 1(41), 153-166.

Tyson, K. (1992). A new approach to relevant scientific research for practitioners: The Heuristic Paradigm. Social Work, 37(6), 541-556.

Urbaniak-Zając, D. (2004). Koncepcja „środowiska” w teorii pedagogiki społecznej Aleksandra Kamińskiego a idea „Lebenswelt”. W: E. Marynowicz-Hetka, H. Kubicka, M. Granosik (red.), Aleksander Kamiński i jego twórczość pedagogiczna. Dyskusja o przeszłości wobec teraźniejszości i przyszłości (s. 99-108). Łódź: Wydawnictwo UŁ.

Weick, A. (1991). The place of science in social work. Journal of Sociology and Social Work, 18(4), 13-34.

Williams, M., Cheal, B. (2002). Can we measure homelessness? A critical evaluation of the method of 'capture-recapture'. International Journal of Social Research Methodology, 5(4), 313-331. DOI: https://doi.org/10.1080/13645570110095346

Wilson, T.P. (1973). Normative and Interpretative Paradigms in Sociology. W: J.D. Douglas (ed.), Understanding Everyday Life. Toward the Reconstruction of Sociological Knowledge (s. 57-79). London: Routledge \& Kegan Paul.

Wroczyński, R. (1974). Pedagogika społeczna. Warszawa: PWN.

Ziemski, S. (1973). Problemy dobrej diagnozy. Warszawa: Wiedza Powszechna.

\section{SUMMARY}

The article aims to present theoretical and methodological assumptions of interpretative assessment along with practical implications of its application. A presentation of a "new" approach of assessing problems in social work was presented with normative diagnosis commonly used in institutions related to social work. The analysis of both ways of recognizing problems in social work was focused on showing the differences between two approaches in their theoretical, methodological and practical dimensions. To clarify the argument, the author used an empirical example of the assessments of one case but made in two approaches. Assessments (normative and interpretative) come from two classes conducted as part of education for students of social pedagogy at the bachelor level. During study, students are required to conduct, first of all, a case diagnosis in a normative approach as part of the subject of training of diagnostic skills and subsequently, as part of the interpretative asessment classes, analyse the same case, based on different theoretical and methodological assumptions.

Keywords: interpretative assessment; normative assessment; social work 